\title{
The place of hydroxychloroquine in modern dermatology
}

\section{Miejsce hydroksychlorochiny we współczesnej dermatologii}

\author{
Aleksandra Dańczak-Pazdrowska', Adrianna Polańska² \\ 'Department of Dermatology, Poznan University of Medical Sciences, Poznan, Poland \\ 2Department of Dermatology and Venereology, Poznan University of Medical Sciences, Poznan, Poland
}

'Katedra Dermatologii, Uniwersytet Medyczny w Poznaniu, Polska

2Zakład Dermatologii i Wenerologii, Uniwersytet Medyczny w Poznaniu, Polska

Dermatol Rev/Przegl Dermatol 2021, I08, I78-190

DOI: https://doi.org//0.5।|4/dr.2021.1086/4

\author{
CORRESPONDING AUTHOR/ \\ ADRES DO KORESPONDENCJI: \\ dr hab. n. med. Aleksandra \\ Dańczak-Pazdrowska \\ Katedra Dermatologii \\ Uniwersytet Medyczny \\ w Poznaniu \\ tel. +48602158360 \\ e-mail: aleksandra.pazdrowska@ \\ onet.eu
}

\begin{abstract}
Hydroxychloroquine has been known since the 1940s. It was initially used to treat malaria. Currently, it has a well-established position in the treatment of lupus erythematosus. The knowledge about its benefits is increasing over time. The mechanism of action of hydroxychloroquine reaches far beyond the immunomodulatory effect, and includes a beneficial effect on glycemic control in patients with diabetes and it is believed to have an effect on normalization of lipid levels, including total cholesterol, LDL cholesterol and triglycerides. In treatment of lupus erythematosus hydroxychloroquine allows decreasing the dose of immunosuppressive drugs, thus not only increasing the treatment efficacy, but also reducing the risk of adverse effects. Possible indications for hydroxychloroquine include also granulomatous skin diseases, such as disseminated annular granuloma, cutaneous sarcoidosis, or reactive granulomatous dermatitis. This article discusses the current indications for hydroxychloroquine with focus on recommended therapeutic regimens and monitoring treatment.
\end{abstract}

\section{STRESZCZENIE}

Hydroksychlorochina jest lekiem znanym od lat 40. ubiegłego wieku. Początkowo stosowano ją w leczeniu malarii, a później tocznia rumieniowatego. Obecnie ma ugruntowaną pozycję w terapii tego ostatniego schorzenia. Jednocześnie znanych jest coraz więcej korzyści płynących ze stosowania leku. Wykraczają one daleko poza działanie immunomodulujące, obejmując liczne aspekty zespołu metabolicznego, a wdrożenie hydroksychlorochiny do leczenia umożliwia ograniczenie dawek leków immunosupresyjnych, nie tylko zwiększając skuteczność, lecz także zmniejszając ryzyko wystąpienia działań niepożądanych. We współczesnej dermatologii, poza schorzeniami z kręgu autoimmunizacyjnych chorób tkanki łącznej, coraz częściej rekomendowana jest $\mathrm{w}$ innych chorobach, $\mathrm{np}$. ziarniniakowych. $\mathrm{W}$ pracy omówiono aktualne wskazania do leczenia hydroksychlorochiną, zwracając szczególną uwagę na zalecane schematy terapeutyczne i postępowanie monitorujące leczenie, mające poprawiać bezpieczeństwo stosowania leku.

Key words: hydroxychloroquine, lupus erythematosus, autoimmune connective tissue diseases, granulomatous skin diseases.

Słowa kluczowe: hydroksychlorochina, toczeń rumieniowaty, autoimmunologiczne choroby tkanki łącznej, choroby ziarniniakowe skóry. 


\section{INTRODUCTION}

The healing properties of the powdered bark of the cinchona tree have been known for hundreds of years and are believed to have been familiar to the ancient Incas. The earliest descriptions of its effectiveness come from the beginning of the $17^{\text {th }}$ century [ 1 , 2]. Over time, in exchange for quinine, which is the main component of the bark responsible for its antimalarial activity, synthetic substitutes for quinine were introduced: mepacrine (1930), chloroquine (CQ; 1934), hydroxychloroquine (HCQ; 1946) $[1,3,4]$. The wide use of mepacrine as an antimalarial drug during World War II contributed to the increased interest of doctors in the beneficial effects of quinine and its derivatives on the course of systemic lupus erythematosus (SLE) $[1,3,4]$. Currently, HCQ is the gold standard of therapy in SLE, but it is also recommended not only in other autoimmune connective tissue diseases but also other conditions, for example granulomatous disorders.

\section{PHARMACOKINETICS}

HCQ is rapidly and almost completely absorbed from the gastrointestinal tract, with peak plasma concentrations reached 1-2 hours after oral ingestion. Eating a meal is not expected to significantly affect this process. About $30-50 \%$ of the substance is bound to the plasma protein. HCQ has a large volume of distribution, which is responsible for drug accumulation in tissues and slows down the elimination process. Its half-life is $32-50$ days. The drug is metabolized in the liver and eliminated mainly by the kidneys. Acidification of the urine promotes faster drug elimination [4-9].

HCQ crosses the placenta. No increased risk of fetal malformations, miscarriages, premature births, low birth weight, or retinopathy has been demonstrated $[3,10,11]$. In contrast, neonatal retinopathy can be caused by HQ $[8,10]$. It is estimated that the excretion of HCQ into breast milk is low and poses no risk to the child $[1,3,8,11]$.

\section{MECHANISM AND EFFECTS OF ACTION}

HCQ exerts immunomodulatory effects at many stages of the immune response. The substance accumulates in lysosomes, leading to the alkalization of their $\mathrm{pH}$ and reducing the activity of lysosomal hydrolases. This is the cause of impaired antigen presentation by MHC class II, which is a selective phenomenon: the function of presenting antigens with high affinity (extrinsic) is preserved, and the function of low affinity (intrinsic) affinity is impaired. This situation explains the immunomodula-

\section{WPROWADZENIE}

Lecznicze właściwości proszku z kory drzewa chinowego znane są od setek lat i miały być nieobce już starożytnym Inkom. Najwcześniejsze opisy potwierdzające jego skuteczność pochodzą z początków XVII wieku $[1,2]$. Z upływem czasu, w zamian za chininę, będącą głównym składnikiem kory odpowiedzialnym za jej działanie przeciwmalaryczne, wprowadzano do użycia syntetyczne substytuty chininy: mepakrynę (1930 r.), chlorochinę (HQ) (1934 r.) i hydroksychlorochinę (HCQ; 1946 r.) $[1,3,4]$. Stosowanie na szeroką skalę mepakryny w czasie II wojny światowej jako leku przeciwmalarycznego zwiększyło zainteresowanie lekarzy jej korzystnym wpływem na przebieg tocznia rumieniowatego układowego (systemic lupus erythematosus - SLE), o czym po raz pierwszy donoszono już pod koniec XIX wieku [1, 3, 4]. Obecnie HCQ stanowi złoty standard terapii w SLE, ale rekomendowana jest także $\mathrm{w}$ innych chorobach $\mathrm{z}$ kręgu chorób autoimmunizacyjnych tkanki łącznej i nie tylko, np. w chorobach ziarniniakowych.

\section{FARMAKOKINETYKA}

HCQ jest szybko i prawie całkowicie wchłaniana z przewodu pokarmowego, a stężenie maksymalne w osoczu osiąga po 1-2 godzinach od przyjęcia drogą doustną. Posiłek nie wpływa istotnie na ten proces. Około 30-50\% substancji wiąże się w osoczu z białkiem. HCQ cechuje duża objętość dystrybucji, co przekłada się na gromadzenie leku w tkankach i spowalnia proces eliminacji. Jego okres półtrwania wynosi 32-50 dni. Lek metabolizowany jest w wątrobie głównie przez enzymy cytochromu P450, a usuwany przede wszystkim przez nerki. Zakwaszenie moczu sprzyja szybszej eliminacji leku [4-9].

HCQ przenika przez łożysko. Nie stwierdzono zwiększonego ryzyka wystąpienia wad płodu, poronień, porodów przedwczesnych, małej masy urodzeniowej, retinopatii $[3,10,11]$. W przeciwieństwie do tego retinopatię u noworodków może powodować $\mathrm{HQ}$ $[8,10]$. Przenikanie HCQ do mleka szacuje się na niewielkie, niestwarzające ryzyka dla dziecka $[1,3,8,11]$.

\section{MECHANIZM I EFEKTY DZIAŁANIA}

HCQ wpływa immunomodulująco na liczne etapy odpowiedzi immunologicznej. Substancja gromadzi się w lizosomach, co prowadzi do alkalizacji ich $\mathrm{pH}$ i zmniejszenia aktywności hydrolaz lizosomalnych. Stanowi to przyczynę upośledzonej prezentacji antygenu przez MHC klasy II, przy czym jest to zjawisko o charakterze wybiórczym: zachowana ma być funkcja prezentacji antygenów z dużym powinowactwem (zewnątrzpochodnych), a upośledzona tych o małym powinowactwie (wewnątrzpochodnych). Taka sytuacja 
tory rather than immunosuppressive mechanism of action of HCQ. It has also been shown that the signal from Toll-like receptors (TLRs), mainly TLR9, is inhibited, which is important since the host's nucleic acids may be their ligands. As a result, dendritic cells, monocytes and macrophages as well as T and B lymphocytes are suppressed. Ultimately, reduced production of pro-inflammatory cytokines, prostaglandins, matrix metalloproteinases and free oxygen radicals is observed $[1,3,11]$.

In addition to the antimalarial effect (significant resistance in many parts of the world should be taken into account), HCQ exhibits antibacterial, antifungal and antiviral effects $[1,11]$. For example, it has been shown to limit replication of the human immunodeficiency virus (HIV). However, in the context of current therapeutic possibilities, the low potency of this effect does not justify the use of the drug in HIV infections. In light of the SARSCoV2 pandemic, the topic of the potential impact of antimalarial drugs on the course of infection has returned. Ultimately, HCQ is not currently recommended for the treatment of COVID-19 patients, as discussed in the recommendations of the Infectious Diseases Society of America (IDSA) [12]. It is worth noting, however, that the publications indicate a lower risk of bacterial infections in SLE patients and a lower number of deaths due to infections in SLE patients treated with HCQ, although conflicting data can be found [13-15].

HCQ also has a hypoglycemic effect, which may be, on the one hand, an undesirable outcome, but on the other hand, it has been shown to have a beneficial effect on glycemic control in patients with both type I and type II diabetes [16, 17]. It has been confirmed that HCQ reduces the risk of diabetes in patients with lupus erythematosus (LE) and rheumatoid arthritis, including those treated with systemic glucocorticoids $[18,19]$.

The drug is believed to normalize lipid levels, including cholesterol, LDL cholesterol and triglycerides, which was suggested not only by studies conducted on a group of patients with SLE, but also on a group suffering from cutaneous lupus erythematosus (CLE), not meeting the criteria for the diagnosis of SLE [20,21]. Despite emerging doubts, the latest meta-analysis supports the hypolipidemic effect of HCQ in patients with SLE [22-25].

The role of HCQ in the prevention and treatment of thrombotic episodes has also been discussed. The drug is believed to inhibit the process of platelet aggregation. Although the role of HCQ in the prevention of blood clots in patients with antiphospholipid antibodies and no clinically evident features of autoimmune diseases in RCTs has not been clearly confirmed [26], recently the results of an open-label, wyjaśnia immunomodulacyjny, a nie immunosupresyjny mechanizm działania HCQ. Stwierdzono także, że hamowaniu podlega sygnał z wewnątrzkomórkowych receptorów żetonowych (Toll-like receptors - TLRs), głównie TLR9, co jest o tyle istotne, że ich ligandami mogą być kwasy nukleinowe gospodarza. W efekcie dochodzi do supresji komórek dendrytycznych, monocytów i makrofagów oraz limfocytów T i B. Ostatecznie obserwuje się zmniejszoną produkcję cytokin prozapalnych, prostaglandyn, metaloproteinaz macierzy i wolnych rodników tlenowych $[1,3,11]$.

Poza efektem przeciwmalarycznym (przy czym należy pamiętać o istotnej oporności w wielu obszarach świata) HCQ ma również działanie przeciwbakteryjne, przeciwgrzybicze i przeciwwirusowe $[1,11]$. Wykazano na przykład, że ma ona ograniczać replikację ludzkiego wirusa niedoboru odporności (HIV). Niewielka siła tego działania nie uzasadnia jednak wykorzystania leku u osób zakażonych HIV w kontekście aktualnych możliwości terapeutycznych. W związku z pandemią SARS-CoV-2 temat potencjalnego wpływu leków przeciwmalarycznych na przebieg infekcji powrócił. Ostatecznie HCQ nie jest obecnie rekomendowana do leczenia chorych na COVID-19, co zostało przedyskutowane w rekomendacjach Amerykańskiego Towarzystwa Chorób Zakaźnych (Infectious Diseases Society of America - IDSA) [12]. Warto natomiast zauważyć publikacje dowodzące mniejszego ryzyka wystąpienia infekcji bakteryjnych u chorych na SLE oraz mniejszej liczby zgonów spowodowanych infekcjami w przebiegu SLE u osób leczonych HCQ, chociaż również w tym zakresie pojawiają się sporne dane [13-15].

Wśród efektów działania HCQ należy wymienić efekt hipoglikemiczny, co może z jednej strony stanowić działanie niepożądane, z drugiej jednak wykazano korzystny wpływ leku na kontrolę glikemii u chorych na cukrzycę zarówno typu 1, jak i typu $2[16,17]$. Potwierdzono, że HCQ zmniejsza ryzyko wystąpienia cukrzycy $\mathrm{u}$ chorych na toczeń rumieniowaty (LE) i reumatoidalne zapalenie stawów, także w grupie leczonej glikokortykosteroidami ogólnie $[18,19]$.

Lek ma normalizować stężenie lipidów, w tym cholesterolu, frakcji LDL cholesterolu i triglicerydów, co sugerowały nie tylko badania prowadzone $\mathrm{u}$ chorych na SLE, lecz także na skórny toczeń rumieniowaty (cutaneous lupus erythematosus - CLE), niespełniających kryteriów rozpoznania SLE [20, 21]. Pomimo pojawiających się wątpliwości, opublikowana w 2019 r. metaanaliza przemawia jednak za efektem hipolipemizjącym HCQ u chorujących na SLE [22-25].

Dyskutowana jest również rola HCQ w profilaktyce i leczeniu epizodów zakrzepowych. Lek ma hamować proces agregacji płytek krwi. Chociaż nie udało się jednoznacznie potwierdzić znaczenia HCQ w profilaktyce zakrzepów u osób z przeciwciałami antyfosfolipidowymi i bez klinicznie jawnych cech chorób autoimmunolo- 
randomized study have been published, indicating the benefits of such prophylaxis in patients with primary antiphospholipid syndrome [27]. A series of observational studies suggest a reduction in the number of thrombotic episodes in patients with SLE [28-30].

In studies on the SLE mouse model, the normalizing effect of HCQ on the endothelial response to vasodilating and vasoconstrictive factors was observed, as well as the reduction of systolic blood pressure caused by it [31]. A recently published meta-analysis indicated a limited risk of cardiovascular events in patients treated with HCQ [32]. It is also expected to reduce the frequency of paroxysmal atrial fibrillation in patients with SLE [33].

HCQ is also reported to inhibit the autophagy process that may underlie resistance to cancer therapies. Therefore, the importance of the drug in adjuvant therapy to sensitize neoplastic cells to treatment has been suggested [34-36]. A prospective observational study showed a lower risk of cancer in SLE patients treated with HCQ [37].

\section{INDICATIONS}

HCQ is the first-line drug in patients with LE and, according to the recommendations, should be used in all patients with SLE, including children, unless there are contraindications $[3,38,39]$. It contributes to the reduction of the risk of disease flare, reduction of the frequency of organ involvement, progression of disease and damage to internal organs, as well as to the reduction of the risk of cardiovascular complications, thromboembolic events, and the development of diabetes and infections and, ultimately, to the risk of death $[13,19,25,30,32,37,40,41]$. A recent study suggests that HCQ contributes to the reduction of polyautoimmunity in SLE patients [42]. The effects of the drug are usually observed about 2-8 weeks after starting the drug [11].

In patients in whom HCQ used alone or in combination with systemic glucocorticosteroids does not allow for the control of disease activity, an immunosuppressant should be added and HCQ treatment continued [38]. HCQ is indicated irrespective of the phase of disease activity, which means the need to continue therapy also in the period of remission (discontinuation significantly increases the risk of relapse) and during pregnancy and lactation [38, $39,43]$. The use of HCQ by pregnant women reduces the risk of SLE exacerbation and reduces disease activity. It is believed that HCQ used during pregnancy reduces the risk of cardiological complications in children whose mothers had circulating anti-Ro/ SSA antibodies $[39,44,45]$. Also in patients with CLE, HCQ is the drug of first choice [46, 47]. According to gicznych w RCT [26], to niedawno opublikowano wyniki badania otwartego randomizowanego, wskazującego na korzyści wynikające $\mathrm{z}$ takiej profilaktyki u chorych z pierwotnym zespołem antyfosfolipidowym [27]. Liczne badania obserwacyjne sugerują ograniczenie liczby epizodów zakrzepowych u chorych na SLE [28-30].

$\mathrm{W}$ badaniach na mysim modelu SLE obserwowano również normalizujący wpływ HCQ na reakcję śródbłonka w stosunku do czynników wazodylatacyjnych i wazokonstrykcyjnych, a także obniżenie pod jej wpływem skurczowego ciśnienia krwi [31]. Niedawno opublikowana metaanaliza wskazała na ograniczone ryzyko wystąpienia epizodów sercowo-naczyniowych u osób leczonych HCQ [32]. Ma ona także zmniejszać częstość występowania napadowego migotania przedsionków u chorych na SLE [33].

HCQ ma również działanie hamujące na proces autofagii, który może leżeć u podstaw oporności na terapie przeciwnowotworowe. Podnosi się znaczenie leku w terapii adiuwantowej w celu uwrażliwienia komórek nowotworowych na leczenie [34-36]. Prospektywne badanie obserwacyjne wykazało mniejsze ryzyko wystąpienia nowotworów u chorych na SLE leczonych HCQ [37].

\section{WSKAZANIA}

HCQ stanowi lek pierwszego wyboru u chorych na LE i zgodnie z rekomendacjami powinna być włączana u wszystkich chorych na SLE, również dzieci, jeśli nie stwierdza się przeciwwskazań [3, 38, 39]. Przyczynia się ona do zmniejszenia ryzyka rzutu choroby, ograniczenia częstości zajęcia, progresji i uszkodzenia w zakresie narządów wewnętrznych, a także do redukcji ryzyka wystąpienia powikłań sercowo-naczyniowych, epizodów zakrzepowo-zatorowych oraz rozwoju cukrzycy lub infekcji, co zmniejsza ostatecznie ryzyko zgonu [13, 19, 25, 30, 32, 37, 40, 41]. Niedawno ukazało się badanie sugerujące, że HCQ przyczynia się do zmniejszenia poliautoimmunizacji u chorych na SLE [42]. Efekty działania leku obserwuje się zwykle po około 2-8 tygodniach od włączenia leku [11].

U chorych, u których HCQ stosowana w monoterapii lub w połączeniu $\mathrm{z}$ glikokortykosteroidami ogólnie nie pozwala na uzyskanie kontroli aktywności choroby, należy dołączyć leki immunosupresyjne, a jednocześnie kontynuować leczenie HCQ [38]. HCQ wskazana jest niezależnie od fazy aktywności choroby, co oznacza kontynuację terapii także w okresie remisji (odstawienie istotnie zwiększa ryzyko nawrotu) oraz w ciąży i w trakcie laktacji [38, 39, 43]. Stosowanie HCQ przez kobiety w ciąży zmniejsza ryzyko zaostrzenia SLE i ogranicza aktywność choroby oraz wpływać ma na redukcję ryzyka wystąpienia powikłań kardiologicznych u dzieci, których matki miały krążące przeciwciała anty-Ro/SSA [39, 44, 45]. Również u chorych na CLE HCQ stanowi lek pierwszego wyboru $[46,47]$. Zgodnie z rekomendacjami 
the recommendations of the European Dermatology Forum, also in this group of patients it should be continued during pregnancy and lactation [46].

In addition to LE, HCQ is mentioned in the recommendations regarding the treatment of: (1) rheumatoid arthritis (recommended only in mild disease), (2) antiphospholipid syndrome (adjunctive therapy, especially in pregnant women), (3) Sjögren's syndrome (recommended for joint lesions and/or skin involvement with the exception of purpura; the drug has no effect on the symptoms of dryness) or (4) dermatomyositis (an adjuvant treatment of skin lesions; the drug has no effect on extra-cutaneous disease symptoms) [48-51].

There is no consensus on the treatment of mixed connective tissue disease (MCTD) or undifferentiated connective tissue disease (UCTD), which is related to the lack of commonly approved classification criteria for these diseases and, as a result, the lack of RCT studies. Most authors, however, recommend the use of non-steroidal anti-inflammatory drugs, HCQ and low doses of systemic glucocorticosteroids in both diseases [52-55]. The effectiveness of HCQ in slowing the progression of UCTD to SLE was suggested based on a retrospective analysis [55]. Two RCTs are currently underway to determine the effectiveness of HCQ in MCTD and UCTD $[56,57]$.

Another indication is granulomatous skin diseases, although evidence comes mainly from observational studies and case reports. It has been suggested that, along with $C Q$, this drug should be considered the first choice in disseminated annular granuloma [58]. HCQ is mentioned as the second-line treatment in sarcoidosis with skin and joint symptoms [59]. It is also expected to be one of the most effective options in the treatment of reactive granulomatous dermatitis [60]. Anecdotal evidence supports the use of the drug in annular elastolytic giant cell granuloma, necrobiosis lipoidica and granulomatous cheilitis [61-63].

HCQ, along with repeated phlebotomy, is the primary form of therapy for porphyria cutanea tarda. Compared to phlebotomy, it is a much more convenient treatment, which should be continued until remission is achieved, which usually occurs after about 7 months [64].

HCQ should also be considered in frontal fibrosing alopecia, but monotherapy is not recommended and the drug is most often combined with e.g. intralesional glucocorticoid injections [65]. At the same time it has limited significance in other forms of lichen planus [66].

In the case of resistance to standard forms of therapy, HCQ may be considered in the treatment of morphea (localized scleroderma), multiforme light eruptions, and urticaria [67-70].
Europejskiego Forum Dermatologii także w tej grupie chorych należy go kontynuować w okresie ciąży i laktacji [46].

Poza LE, HCQ wymieniana jest w rekomendacjach dotyczących leczenia: 1) reumatoidalnego zapalenia stawów (zalecana jedynie w łagodnym przebiegu choroby), 2) zespołu antyfosfolipidowego (leczenie wspomagające, zwłaszcza u kobiet w okresie ciąży), 3) zespołu Sjőgrena (wskazana przy zmianach stawowych i/lub zajęciu skóry z wyłączeniem plamicy, nie ma wpływu na objawy suchości) czy 4) zapalenia skórno-mięśniowego (jako leczenie adiuwantowe zmian skórnych, nie ma wpływu na pozaskórne objawy choroby) [48-51].

Niestety nie ma konsensusu dotyczącego leczenia mieszanej choroby tkanki łącznej (mixed connective tissue diseases - MCTD) i niezróżnicowanej choroby tkanki łącznej (undifferentiated connective tissue diseases - UCTD), co powiązane jest $\mathrm{z}$ brakiem powszechnie uznanych kryteriów klasyfikacyjnych tych schorzeń i w rezultacie brakiem badań RCT. Większość autorów zaleca jednak stosowanie niesteroidowych leków przeciwzapalnych, HCQ i niskich dawek glikokortykosteroidów ogólnie w obu jednostkach chorobowych [52-55]. Skuteczność HCQ w spowolnieniu progresji UCTD do SLE sugerowano na podstawie analizy retrospektywnej [55]. Aktualnie prowadzone są RCT mające na celu potwierdzenie skuteczności HCQ w MCTD i UCTD [56, 57].

Kolejnym wskazaniem są choroby ziarniniakowe skóry, chociaż dowody pochodzą głównie z badań obserwacyjnych i opisów przypadków. Sugeruje się, że HCQ na równi z HQ powinna być rozważana jako lek pierwszego wyboru w rozsianym ziarniniaku obrączkowatym [58]. HCQ jest wymieniana jako leczenie drugiego wyboru w sarkoidozie przy objawach skórnych i stawowych [59]. Ma być też jedną ze skuteczniejszych opcji w leczeniu reaktywnego ziarniniakowego zapalenia skóry [60]. Anegdotyczne dowody przemawiają za stosowaniem leku w obrączkowatym ziarniniaku elastolitycznym, obumieraniu tłuszczowatym i ziarniniakowym zapaleniu warg [61-63].

HCQ, na równi z powtarzanymi upustami krwi, stanowi podstawową formę terapii porfirii skórnej późnej. W porównaniu z krwioupustami jest dużo dogodniejszą postacią leczenia, które należy kontynuować aż do uzyskania remisji, co zwykle następuje po około 7 miesiącach [64].

Sugeruje się również przydatność HCQ w łysieniu bliznowaciejącym czołowym, przy czym nie zaleca się monoterapii i lek najczęściej łączony jest np. z doogniskowymi iniekcjami glikokortykosteroidów [65]. Jednocześnie ma on ograniczone znaczenie $w$ innych postaciach liszaja płaskiego [66].

W przypadku oporności na standardowe formy terapii można rozważyć wdrożenie HCQ w leczeniu morphea (twardziny ograniczonej), wielopostaciowych osutek świetlnych i pokrzywce [67-70]. 
HCQ dose should be adjusted to the patient's body weight. In the active period of SLE, a dose not exceeding $5 \mathrm{mg} / \mathrm{kg}$ of the current body weight is suggested, assuming that the maximum daily dose is $400 \mathrm{mg} \mathrm{[3}$, $10,38,71]$. Earlier, as the substance does not distribute in adipose tissue, it was recommended to convert the dose according to the proper body weight, and therefore it was higher $(6.5 \mathrm{mg} / \mathrm{kg})$. However, it has been noted that this may result in drug overdose and a higher risk of side effects (especially retinopathy) in people with a low body mass index $[38,71,72]$. It is important to emphasize that the studies confirming the effectiveness of HCQ were carried out at the dose of $6.5 \mathrm{mg} / \mathrm{kg}$ [38]. Recently, results have been published according to which the use of doses of $\leq 5 \mathrm{mg} / \mathrm{kg}$ does not affect the effectiveness of therapy [73]. Taking the currently recommended dose, a person weighing $40 \mathrm{~kg}, 60 \mathrm{~kg}$, or $80 \mathrm{~kg}$ should receive $200 \mathrm{mg}$, $300 \mathrm{mg}$, or $400 \mathrm{mg}$, respectively, of the drug per day. Due to the long half-life of the drug and taking into account the available grammage of tablets containing HCQ, when administering $300 \mathrm{mg} /$ day, a scheme of alternating 400 and $200 \mathrm{mg}$ on consecutive days is suggested $[3,10]$. In patients with longterm remission, dose reduction may be considered, although there are no convincing data from the literature to support such a recommendation. Its complete discontinuation is not recommended [38].

In most of the other diseases described above, doses of 200-400 mg/day are routinely recommended $[50,59]$. The exception is porphyria cutanea tarda, where it is recommended to use $100 \mathrm{mg}$ of HCQ twice a week [64].

\section{FACTORS INFLUENCING THE EFFECTIVENESS OF TREATMENT}

The issue of the ineffectiveness of HCQ, which is supposed to be the result of the use of sub-optimal doses of the drug or patient non-compliance, and in turn causes too low HCQ concentration in the blood, is raised. Values greater than $750 \mathrm{ng} / \mathrm{ml}$ are considered correct $[9,74,75]$. Most current guidelines do not recommend the routine measurement of HCQ levels, although conflicting views exist [3, 9, 38, 46, 76].

The potential worse effectiveness of HCQ in cigarette smokers suffering from LE has also been debated. It has been postulated that one of the mechanisms by which nicotine would antagonize the action of HCQ would be to enhance the TLR 9 response [77]. Currently, however, the prevailing view is that cigarette smoking itself contributes to a worse course of $\mathrm{LE}$, and is a risk factor for the development of the disease in genetically predisposed individuals $[10$,

\section{DAWKOWANIE}

Dawka HCQ powinna być dostosowana do masy ciała chorego. W okresie aktywnym SLE sugeruje się dawkę nieprzekraczającą $5 \mathrm{mg} / \mathrm{kg}$ aktualnej masy ciała przy założeniu, że maksymalna dawka dobowa to $400 \mathrm{mg}[3,10,38,71]$. Wcześniej ze względu na brak dystrybucji substancji w tkance tłuszczowej rekomendowano przeliczanie dawki na należną masę ciała i dlatego była ona wyższa $(6,5 \mathrm{mg} / \mathrm{kg})$. Zauważono jednak, że może to skutkować przedawkowaniem leku u osób z obniżonym wskaźnikiem masy ciała, a tym samym większym ryzykiem wystąpienia działań niepożądanych, szczególnie retinopatii [38, 71, 72]. Należy podkreślić, że badania potwierdzające skuteczność HCQ były przeprowadzane przy stosowaniu dawki $6,5 \mathrm{mg} / \mathrm{kg}$ [38]. Ostatnio opublikowano jednak wyniki, według których stosowanie dawek $\leq 5 \mathrm{mg} / \mathrm{kg}$ nie wpływa na skuteczność terapii [73]. Przyjmując aktualnie rekomendowaną dawkę, w uproszczeniu: osoba ważąca $40 \mathrm{~kg}$ powinna otrzymywać 200 mg leku na dobę, osoba ważąca 60 kg $300 \mathrm{mg}$, a osoba ważąca $80 \mathrm{~kg}$ - $400 \mathrm{mg}$. Z uwagi na długi okres półtrwania leku i uwzględniając dostępną gramaturę tabletek zawierających $\mathrm{HCQ}$, w przypad$\mathrm{ku}$ podawania $300 \mathrm{mg} /$ dobę, sugeruje się schemat naprzemiennego stosowania $400 \mathrm{mg}$ i $200 \mathrm{mg}$ w kolejne dni $[3,10]$. U chorych z długotrwającą remisją można rozważyć zmniejszenie dawki leku, chociaż brakuje przekonujących danych z piśmiennictwa potwierdzających takie rekomendacje. Nie zaleca się całkowitego jego odstawienia [38].

W przypadku większości pozostałych powyżej opisanych jednostek również rekomenduje się dawki 200-400 mg/dobę [50, 59]. Wyjątek stanowi porfiria skórna późna, w przypadku której zaleca się podawanie $100 \mathrm{mg}$ HCQ 2 razy w tygodniu [64].

\section{CZYNNIKI WPŁYWAJĄCE NA SKUTECZNOŚĆ LECZENIA}

Podnosi się kwestię braku skuteczności HCQ, która ma wynikać ze stosowania suboptymalnych dawek leku lub niestosowania się chorego do zaleceń, co z kolei może skutkować zbyt niskim stężeniem HCQ we krwi. Za prawidłowe przyjmuje się wartości większe niż 750 ng/ml [9, 74, 75]. Większość aktualnych wytycznych nie zaleca jednak rutynowych pomiarów stężenia HCQ, chociaż nie jest to stanowisko wszystkich ekspertów [3, 9, 38, 46, 76].

Dyskusje wzbudza również potencjalna gorsza skuteczność HCQ u palaczy tytoniu. Postulowano, że jednym z mechanizmów, w którym nikotyna miałaby antagonizować działanie HCQ, byłoby wzmocnienie odpowiedzi z TLR 9 [77]. Obecnie jednak przeważa pogląd, że palenie tytoniu jako wyłączny czynnik 
78]. On the other hand, it was suggested that smokers less frequently complied with the recommendations, which could ultimately result in suboptimal blood HCQ levels [78]. The current treatment guidelines for either SLE or CLE include smoking cessation as a preventive measure $[38,46]$.

\section{SIDE EFFECTS}

It should be noted that HCQ is a well-tolerated drug and the frequency of adverse events is not high [11]. The most common side effects are gastrointestinal complaints such as nausea, vomiting, diarrhea, and loss of appetite $[1,3,10]$. They are usually mild and disappear on discontinuation of the drug, dose reduction or administration in two divided doses. To minimize the risk of these disorders, it is suggested to take the drug with a meal. Occasionally an increase in transaminase levels may be observed. Caution is recommended in patients with liver disease [3, 10, 11, 79].

The second most common group of side effects is dermatological. Usually these are measles and psoriasis-like exanthems. In the case of their mild course, improvement is usually achieved after drug discontinuation, and then doses lower than initially can be introduced again [10, 79]. Gray-blue discoloration is also quite common and may affect $7-29 \%$ of patients. They can be located anywhere on the skin, mucous membranes or nails. The presence of extravasation within the skin, and thus the ironrich hemosiderin, which stimulates melanogenesis, predisposes to the formation of discoloration. A relationship has been demonstrated between the presence of discoloration and the use of anticoagulants and antiplatelet drugs. Discontinuation of the drug does not always result in resolution of the changes [10, 79-81]. Skin pruritus has also been reported, although it is worth noting that this may be a symptom of CLE $[79,82]$. HCQ may induce a drug reaction in the form of toxic epidermal necrolysis or acute generalized exanthematous pustulosis (AGEP), and although the latter is uncommon, HCQ is mentioned as one of the most frequent causes $[79,83]$. Photosensitivity, urticaria, erythema multiforme or drug reactions with eosinophilia and systemic symptoms (DRESS), hair loss, hair discoloration and stomatitis have been reported occasionally [79]. Desensitization regimens have been described in the literature; they allow for the resumption of HCQ treatment in the case of initial drug hypersensitivity [84]. The previously suggested influence on the course of psoriasis does not seem to be confirmed in the literature [85].

The effect of HCQ on vision is the most widely discussed and of concern for both physicians and przyczynia się do gorszego przebiegu LE i jest czynnikiem ryzyka rozwoju choroby u osób predysponowanych genetycznie [10, 78]. Sugeruje się jednak, że osoby palące rzadziej stosują się do zaleceń, co ostatecznie może skutkować suboptymalnym stężeniem HCQ we krwi [78]. Aktualne wytyczne dotyczące leczenia zarówno SLE, jak i CLE zakładają zaniechanie palenia tytoniu $\mathrm{w}$ ramach profilaktyki $[38,46]$.

\section{DZIAŁANIA NIEPOŻACDANE}

Należy zaznaczyć, że HCQ jest lekiem dobrze tolerowanym i częstość występowania zdarzeń niepożądanych nie jest duża [11]. Najczęstszym są dolegliwości ze strony przewodu pokarmowego $\mathrm{w}$ postaci nudności, wymiotów, biegunek i utraty apetytu $[1,3,10]$. Zwykle mają one przebieg łagodny i ustępują wraz z odstawieniem leku, zmniejszeniem jego dawki lub podawaniem w dwóch dawkach podzielonych. W celu zminimalizowania tych zaburzeń sugeruje się przyjmowanie leku z posiłkiem. Niekiedy można obserwować zwiększenie aktywności aminotransferaz. Zaleca się ostrożność u chorych z chorobą wątroby [3, 10, 11, 79].

Drugimi co do częstości występowania są powikłania dermatologiczne, przy czym zazwyczaj są to osutki odro- i łuszczycopodobne. W przypadku ich łagodnego przebiegu zwykle poprawę uzyskuje się po odstawieniu leku, po czym można podjąć próbę jego ponownego wdrożenia z wykorzystaniem mniejszych niż początkowo dawek [10, 79]. Nierzadkim powikłaniem, bo mającym dotyczyć 7-29\% leczonych, są szaroniebieskie przebarwienia, które mogą wystąpić w każdej lokalizacji na skórze, błonach śluzowych i paznokciach. Do ich pojawienia się ma predysponować obecność wynaczynień i w ich konsekwencji bogatej w żelazo hemosyderyny, co ma pobudzać melanogenezę. Stwierdzono związek między obecnością przebarwień i stosowaniem leków przeciwkrzepliwych i przeciwpłytkowych. Nie zawsze obserwuje się całkowite ustąpienie zmian po odstawieniu leku [10, 79-81]. Opisywany był również świąd skóry, chociaż warto zauważyć, że może to być objaw CLE $[79,82]$. HCQ może wzbudzić reakcje polekowe o typie toksycznej nekrolizy naskórka lub ostrej uogólnionej osutki krostkowej (acute generalized exanthematous pustulosis - AGEP) i chociaż ta ostatnia nie jest częstym powikłaniem, to HCQ wymieniana jest jako jedna z najczęstszych jej przyczyn $[79,83]$. Sporadycznie opisywane są: nadwrażliwość na światło, pokrzywka, rumień wielopostaciowy lub reakcja polekowa z eozynofilią i objawami ogólnymi (drug reaction with eosinophilia and systemic symptoms - DRESS), łysienie, przebarwienie włosów, zapalenie błony śluzowej jamy ustnej [79]. W piśmiennictwie opisywane są schematy desensytyzacji pozwalające na powrót do leczenia HCQ przy stwierdzanej początkowo nadwrażliwości na lek [84]. Wydaje się, że sugerowany 
patients, as a potentially irreversible side effect. The most serious complication is retinopathy. It affects up to $7.5 \%$ of treated people. The earlier data suggesting a lower risk of HCQ-related retinopathy most likely resulted from the use of less precise screening techniques than currently used [71]. The essence of this phenomenon is the deposition of the drug in the retinal pigment layer through binding to melanin, which leads to bilateral "buffalo-eye" maculopathy, which is based on atrophy of the retinal pigment epithelium in the perifoveal area conserving macular structures. Finally, large areas of the retina may become atrophic $[11,86,87]$. Clinically, in the initial stages of the disease, the patient remains asymptomatic. In subsequent stages, paracentral scotoma may appear, visual acuity may deteriorate, and eventually the patient may experience loss of central vision, loss of peripheral visual field, and deterioration of twilight vision $[86,87]$.

The risk of retinopathy increases significantly if the patient takes a daily dose $>5 \mathrm{mg} / \mathrm{kg}$ of current body weight. In this situation, the risk of retinopathy after 10 years was $10 \%$. With doses of $4-5 \mathrm{mg} / \mathrm{kg}$, the risk after 10 years was $<2 \%$ [71]. Another risk factor is the length of use of the drug. The probability increases rapidly after 5 years of continuous treatment and after exceeding a cumulative dose of $1000 \mathrm{~g}$. After 20 years of treatment with doses up to $4-5 \mathrm{mg} / \mathrm{kg}$, the risk of retinopathy was $20 \%$ [71]. This problem is much more common in people with comorbidities, especially renal diseases. A loss of renal function by $50 \%$ is expected to double the risk of retinopathy [71]. Pre-existing retinal diseases and maculopathy are also important. The latter is a relative contraindication to HCQ as it may mask early retinopathy. The risk of complications increases with the use of tamoxifen $[10,71]$. Total elimination of HCQ toxicity towards the eye is not possible, but adherence to the correct dosage reduces its likelihood and regular ophthalmic screening can detect retinopathy at an early, asymptomatic stage. Discontinuation of HCQ in this case prevents further progression of the complication. Current screening recommendations were provided by the American Academy of Ophthalmology (2016 update) and the Royal College of Ophthalmologists (2018) [86, 87]. These recommendations, from a dermatological point of view, do not differ significantly. They recommend that the first eye examination should occur within the $1^{\text {st }}$ year of treatment, preferably within the first 6 months. Then, in patients without concomitant risk factors, the next follow-up is recommended 5 years after the implementation of HCQ treatment and annually for subsequent years. If risk factors are present, monitoring should be performed annu- wcześniej wpływ na przebieg łuszczycy nie znajduje potwierdzenia w danych literaturowych [85].

Najszerzej dyskutowanym i budzącym niepokój zarówno wśród lekarzy, jak i chorych, będąc potencjalnie nieodwracalnym działaniem niepożądanym, jest wpływ HCQ na wzrok. Najpoważniejszym powikłaniem jest retinopatia. Problem ten ma dotyczyć nawet 7,5\% leczonych, a wcześniejsze dane sugerujące mniejsze ryzyko wynikały najprawdopodobniej ze stosowania mniej dokładnych technik skriningu niż współcześnie wykorzystywane [71]. Istotą zjawiska jest odkładanie się leku w warstwie barwnikowej siatkówki przez wiązanie się z melaniną, co prowadzi do obustronnej makulopatii typu „bawole oko”, która polega na atrofii nabłonka barwnikowego siatkówki w obszarze okołodołkowym przy zaoszczędzeniu struktur plamki. Ostatecznie atrofii mogą ulec rozległe obszary siatkówki [11, 86, 87]. Klinicznie, w początkowych stadiach choroby pacjent nie ma objawów, w kolejnych może pojawić się paracentralny mroczek, a ostrość wzroku może ulec pogorszeniu i w końcu chory może doświadczać utraty widzenia centralnego, utraty obwodowego pola widzenia i pogorszenia widzenia o zmierzchu $[86,87]$.

Ryzyko retinopatii istotnie zwiększa się, jeśli chory przyjmuje dawkę dobową $>5 \mathrm{mg} / \mathrm{kg}$ aktualnej masy ciała. W takiej sytuacji ryzyko retinopatii po 10 latach wynosiło 10\%. Przy stosowaniu dawek wynoszących 4-5 mg/ kg ryzyko to po 10 latach było poniżej 2\% [71]. Dodatkowymi czynnikami ryzyka są czas trwania leczenia, przy czym ryzyko zwiększa się gwałtownie po 5 latach ciągłej kuracji oraz po przekroczeniu dawki kumulacyjnej 1000 g. Po 20 latach kuracji dawkami sięgającymi 4$5 \mathrm{mg} / \mathrm{kg}$ ryzyko retinopatii wynosiło $20 \%$ [71]. Zdecydowanie częściej problem ten dotyczy osób obciążonych chorobami współistniejącymi, przede wszystkim chorobami nerek. Utrata funkcji nerek o $50 \%$ podwaja ryzyko wystąpienia retinopatii [71]. Znaczenie mają również wcześniej występujące schorzenia siatkówki i makulopatia. Ta ostatnia stanowi względne przeciwwskazanie do $\mathrm{HCQ}$, ponieważ może maskować wczesną retinopatię. Ryzyko wystąpienia powikłania zwiększa się przy jednoczesnym stosowaniu tamoksyfenu [10, 71]. Całkowita eliminacja toksyczności HCQ względem oka nie jest możliwa, ale przestrzeganie właściwego dawkowania zmniejsza jej prawdopodobieństwo, a regularny skrining okulistyczny może wykryć retinopatię na wczesnym, bezobjawowym etapie. Odstawienie HCQ w takim przypadku zapobiega dalszej progresji powikłania. Aktualne zalecenia dotyczące skriningu przedstawione zostały przez Amerykańską Akademię Okulistyki (American Academy of Ophtalmology) (aktualizacja z 2016 r.) oraz The Royal College of Ophtalmologists z 2018 r. [86, 87]. Zalecenia te, $\mathrm{z}$ dermatologicznego punktu widzenia, nie różnią się istotnie. Sugerują one, aby pierwsza kontrola okulistyczna nastąpiła w czasie 1. roku leczenia, najlepiej w czasie pierwszych 6 miesięcy. Następnie u chorych bez 
ally from the start $[86,87]$. This evaluations should include at least the examination of the fundus with its color photography and spectral-domain optical coherence imaging (SD-OCT), and additionally also take into account the computerized examination of the field of view 10-2 in the SITA strategy and autofluorescence of the eye fundus $[86,87]$. The Amsler test is currently not recommended [86, 87]. It should be noted that in children the risk of HCQ-related retinopathy has not been clearly defined and therefore some authors recommend annual ophthalmological screening [3].

HCQ can also cause vortex keratopathy, which is a reversible process, and the changes may subside even with continued treatment. Symptoms of this condition are blue-green ring vision, changes in the halo around light sources, deterioration of night vision, decreased visual acuity, photophobia, dry eyes, and eyelid dermatitis. Other rare complications are transient accommodation disturbances and accelerated cataract development [88].

Although myopathy is a relatively rare complication, it may affect the heart muscle $[89,90]$. The incidence of HCQ-associated cardiomyopathy is believed to be underestimated and in many cases unrecognized, with less occurrence at lower doses. Clinically, it may present as congestive heart failure or conduction disturbances. The risk of death is estimated to be as high as $45 \%$. Diagnostics requires a myocardial biopsy. Discontinuation of HCQ is an indispensable element of treatment, after which usually improvement is observed, but not complete recovery. The annual electrocardiogram may increase the likelihood of early diagnosis [9-11, 90]. In patients chronically treated with both CQ and HCQ, clinically asymptomatic elevated levels of phosphocreatine kinase have been observed [89]. HCQ may also occasionally cause neuromyopathy in the form of progressive weakening of the proximal muscles of the lower extremities [11]. Contrary to previous concerns, the drug is well tolerated by patients with comorbid myasthenia gravis [11].

People with a deficiency of glucose-6-phosphate dehydrogenase can potentially develop hemolysis, but this does not happen with the standard recommended doses. Therefore, routine screening for enzymopathy is not recommended $[10,91]$. Agranulocytosis and neutropenia are also mentioned, but there are doubts about the relevance of their association with the use of HCQ [3, 10, 11].

HCQ may occasionally cause episodes of hypoglycemia [92]. Mood and sleep disturbances as well as irritability have been described, but they usually occur at doses higher than those typically used in dermatology $[3,11]$. Ototoxicity has also been reported, although with the currently recommended współistniejących czynników ryzyka zaleca się kolejne badanie po upływie 5 lat od wdrożenia leczenia HCQ i corocznie w kolejnych latach. W przypadku występowania czynników ryzyka kontrole od początku należy wykonywać raz w roku $[86,87]$. Ocena ta obejmuje co najmniej badanie dna oka $\mathrm{z}$ jego kolorową fotografią i spektralną optyczną koherentną tomografię oka (spectral-domain optical coherence imaging - SD-OCT), a dodatkowo należy uwzględnić też komputerowe badanie pola widzenia 10-2 w strategii SITA i autofluorescencję dna oka $[86,87]$. Nie zaleca się obecnie wykonywania testu Amslera [86, 87]. Należy zauważyć, że u dzieci ryzyko rozwoju retinopatii związanej z HCQ nie zostało jednoznacznie określone i z tego względu niektórzy autorzy zalecają coroczne kontrole okulistyczne [3].

HCQ może powodować także keratopatię wirowatą, która jest procesem odwracalnym, a zmiany mogą ustąpić nawet pomimo kontynuacji leczenia. Objawami tego schorzenia są widzenie niebiesko-zielonych pierścieni, zmiany typu halo wokół źródeł światła, pogorszenie widzenia nocnego, pogorszenie ostrości wzroku, światłowstręt, suchość oczu, zapalenie skóry powiek. Do innych rzadkich powikłań należą przejściowe zaburzenia akomodacji i przyspieszony rozwój zaćmy [88].

Miopatia stanowi stosunkowo rzadkie powikłanie, niemniej może dotyczyć mięśnia sercowego [89, 90]. Uważa się, że częstość występowania kardiomiopatii związanej z HCQ jest niedoszacowana i w wielu przypadkach pozostaje ona nierozpoznana, przy czym jest ona rzadsza przy stosowaniu mniejszych dawek leku. Klinicznie może objawiać się jako zastoinowa niewydolność serca lub zaburzenia przewodnictwa. Ryzyko zgonu sięga nawet $45 \%$. Diagnostyka wymaga wykonania biopsji mięśnia sercowego. Nieodzownym elementem leczenia jest odstawienie HCQ, po czym zwykle obserwuje się poprawę, ale nie całkowite ustąpienie zmian. Coroczna kontrola elektrokardiograficzna może zwiększyć prawdopodobieństwo wczesnego rozpoznania [9-11, 90]. U przewlekle leczonych zarówno HQ, jak i HCQ, obserwowano klinicznie bezobjawowe zwiększone stężenie kinazy fosfokreatynowej [89]. HCQ może też sporadycznie być przyczyną neuromiopatii przebiegającej w postaci postępującego osłabienia mięśni proksymalnych kończyn dolnych [11]. Wbrew wcześniejszym obawom lek jest dobrze tolerowany przez chorych z współtowarzyszącą miastenią [11].

U osób z niedoborem dehydrogenazy glukozo-6-fosforanowej może potencjalnie dojść do hemolizy, ale nie zdarza się to przy standardowo zalecanych dawkach leku. Dlatego też rutynowe poszukiwanie enzymopatii nie jest rekomendowane [10,91]. Jako powikłanie wymienia się również agranulocytozę i leukopenię, chociaż istnieją wątpliwości co do zasadności ich wiązania ze stosowaniem HCQ [3, 10, 11].

HCQ może być sporadycznie przyczyną epizodów hipoglikemii [92]. Opisywano zaburzenia nastroju i snu, 
dosages of the drug, it appears that hearing impairment in patients with SLE treated with HCQ results from the disease rather than treatment [93].

\section{SUMMARY}

HCQ, introduced to the treatment of malaria and LE in the middle of the last century, now turns out to be a drug with more and more indications. In dermatology, it is worth noting its use for example in granulomatous diseases with presentation on the skin. Its actions are not limited to the immunomodulatory or antimicrobial effect, but they bring a number of benefits in terms of various aspects of the metabolic syndrome or the phenomena underlying oncogenesis. At the same time, the better known side effects of the drug allowed for the development of monitoring and dosing regimens, which significantly improved the safety of its use.

\section{CONFLICT OF INTEREST}

Aleksandra Dańczak-Pazdrowska gave lectures sponsored by Medac. Adrianna Polańska declare no conflict of interest. drażliwość, ale zwykle pojawiają się one przy stosowaniu dawek wyższych niż standardowo stosowane w dermatologii $[3,11]$. Sugerowano również ototoksyczność, chociaż przy obecnie rekomendowanych dawkach leku wydaje się, że zaburzenia słuchu obserwowane u chorych na SLE leczonych HCQ wynikają raczej z choroby podstawowej, a nie stosowanego leczenia [93].

\section{PODSUMOWANIE}

Wprowadzona do leczenia malarii i LE w połowie ubiegłego wieku HCQ współcześnie okazuje się lekiem o coraz szerszych wskazaniach. Z zakresu dermatologii warto w tym kontekście zauważyć np. choroby ziarniniakowe z prezentacją na skórze. Jej działania nie ograniczają się jedynie do efektu immunomodulującego lub przeciwdrobnoustrojowego, ale niosą ze sobą szereg korzyści w zakresie różnych aspektów zespołu metabolicznego lub zjawisk leżących u podłoża onkogenezy. Jednocześnie coraz lepiej poznane efekty niepożądane leku pozwoliły na wypracowanie schematów monitorowania i dawkowania, co istotnie poprawiło bezpieczeństwo jego stosowania.

\section{KONFLIKT INTERESÓW}

Aleksandra Dańczak-Pazdrowska wygłaszała prelekcje sponsorowane przez Medac. Adrianna Polańska nie zgłasza konfliktu interesów.

\section{References}

\section{Piśmiennictwo}

1. Ben-Zvi I., Kivity S., Langevitz P., Shoenfeld Y.: Hydroxychloroquine: from malaria to autoimmunity. Clin Rev Allerg Immunol 2012, 42, 145-153.

2. Kacprzak K., Czarnecki P.: Alkaloidy kory chinowej - małe cząsteczki, które wiele mogą. Wiad Chem 2013, 67, 443-493.

3. Chew C.Y., Mar A., Nikpour M., Saracino A.M.: Hydroxychloroquine in dermatology: new perspectives on an old drug. Australas J Dermatol 2020, 61, e150-e157.

4. Sardana K., Sinha S., Sachdeva S.: Hydroxychloroquine in dermatology and beyond: recent update. Indian Dermatol Online J 2020, 11, 453-464.

5. Lim H.S., Im J.S., Cho J.Y, Bae K.S, Klein T.A, Yeom J.S., et al.: Pharmacokinetics of hydroxychloroquine and its clinical implications in chemoprophylaxis against malaria caused by Plasmodium vivax. Antimicrob Agents Chemother 2009, 53, 1468-1475.

6. Browning D.J.: Pharmacology of chloroquine and hydroxychloroquine. Hydroxychloroquine and Chloroquine Retinopathy 2014, 35-63. Doi: 10.1007/978-1-4939-0597-3_2.

7. Tanaka E., Taniguchi A., Urano W., Yamanaka H., Kamatani N.: Pharmacogenetics of disease-modifying anti-rheumatic drugs. Best Pract Res Clin Rheumatol 2004, 18, 233-247.

8. Qozi M., Cantrell F.L.: Chloroquine/Hydroxychloroquine. [In]: Encyclopedia of Toxicology. $3^{\text {rd }}$ ed. Wexler P. (ed.). Academic Press, London, 2014, 913-915.

9. Shukla A.M., Shukla A.W.: Expanding horizons for clinical applications of chloroquine, hydroxychloroquine, and related structural analogues. Drugs Context 2019, 8, 2019-9-1. DOI: 10.7573/dic.2019-9-1.

10. Fernandez A.: Updated recommendations on the use of hydroxychloroquine in dermatologic practice. J Am Acad Dermatol 2017, $76,1176-1182$.

11. Costedoat-Chalumeau N., Dunogué B., Morel N., Le Guern V., Guettrot-Imbert G.: Hydroxychloroquine: a multifaceted treatment in lupus. Presse Med 2014, 43, e167-e180.

12. Bhimraj A., Morgan R.L., Shumaker A.H., Lavergne V., Baden L., Cheng V.C., et al.: Infectious Diseases Society of America Guidelines on the Treatment and Management of Patients with COVID-19. Infectious Diseases Society of America 2021; Version 4.2.0. Available at https://www.idsociety.org/practice-guideline/covid-19-guideline-treatment-and-management/. Accessed 16.05.2021.

13. Sisó A., Ramos-Casals M., Bové A., Brito-Zerón P., Soria N., Muñoz S., et al.: Previous antimalarial therapy in patients diagnosed with lupus nephritis: influence onoutcomes and survival. Lupus 2008, 17, 281-288. 
14. Danza A., Ruiz-Irastorza G.: Infection risk in systemic lupus erythematosus patients: susceptibility factors and preventive strategies. Lupus 2013, 22, 1286-1294.

15. Sakai R., Honda S., Tanaka E., Majima M., Konda N., Takada H., et al.: The risk of hospitalized infection in patients with systemic lupus erythematosus treated with hydroxychloroquine. Lupus 2020, 29, 1712-1718.

16. Rekedal L.R., Massarotti E., Garg R., Bhatia R., Gleeson T., Lu B., et al.: Changes in glycosylated hemoglobin after initiation of hydroxychloroquine or methotrexate treatment in diabetes patients with rheumatic diseases. Arthritis Rheum 2010, 62, $3569-3573$.

17. Hage M.P., Al-Badri M.R., Azar S.T.: A favorable effect of hydroxychloroquine on glucose and lipid metabolism beyond its anti-inflammatory role. Ther Adv Endocrinol Metab 2014, 5, 77-85.

18. Penn S.K., Kao A.H., Schott L.L., Elliott J.R., Toledo F.G., Kuller L., et al.: Hydroxychloroquine and glycemia in women with rheumatoid arthritis and systemic lupus erythematosus. J Rheumatol 2010, 37, 1136-1142.

19. Chen Y.M., Lin C.H., Lan T.H., Chen H.H., Chang S.N., Chen Y.H., et al.: Hydroxychloroquine reduces risk of incident diabetes mellitus in lupus patients in a dose-dependent manner: a population-based cohort study. Rheumatology 2015, 54, 1244-1249.

20. Wallace D.J., Metzger A.L., Stecher V.J., Turnbull B.A., Kern P.A.: Cholesterol-lowering effect of hydroxychloroquine in patients with rheumatic disease: reversal of deleterious effects of steroids on lipids. Am J Med 1990, 89, 322-326.

21. Ikeda T., Kanazawa N., Furukawa F.: Hydroxychloroquine administration for Japanese lupus erythematosus in Wakayama: a pilot study. J Dermatol 2012, 39, 531-535.

22. Kavanaugh A., Adams-Huet B., Jain R., Denke M., McFarlin J.: Hydroxychloroquine effects on lipoprotein profiles (the HELP trial): a double-blind, randomized, placebo-controlled, pilot study in patients with systemic lupus erythematosus. J Clin Rheumatol 1997, 3, 3-8.

23. Borba E.F., Bonfa E.: Longterm beneficial effect of chloroquine diphosphate on lipoprotein profile in lupus patients with and without steroid therapy. J Rheumatol 2001, 28, 780-785.

24. Ali Abdalla M., El Desouky S., Sayed Ahmed A.: Clinical significance of lipid profile in systemic lupus erythematosus patients: relation to disease activity and therapeutic potential of drugs. Egypt Rheumatol 2017, 39, 93-98.

25. Tao C.Y., Shang J., Chen T., Yu D., Jiang Y.M., Liu D., et al.: Impact of antimalarial (AM) on serum lipids in systemic lupus erythematosus (SLE) patients: a systematic review and meta-analysis. Medicine 2019, 98, e15030.

26. Erkan D., Unlu O., Sciascia S., Belmont H.M., Ware Branch D., Cuadrado M.J., et al.: Hydroxychloroquine in the primary thrombosis prophylaxis of antiphospholipid antibody positive patients without systemic autoimmune disease. Lupus 2018, 27, 399-406.

27. Kravvariti E., Koutsogianni A., Samoli E., Sfikakis P.P., Tektonidou M.G.: The effect of hydroxychloroquine on thrombosis prevention and antiphospholipid antibody levels in primary antiphospholipid syndrome: a pilot open label randomized prospective study. Autoimmun Rev 2020, 19, 102491.

28. Wallace D.J.: Does hydroxychloroquine sulfate prevent clot formation in systemic lupus erythematosus? Arthritis Rheum 1987, 30, 1435-1436.

29. Kaiser R., Cleveland C.M., Criswell L.A.: Risk and protective factors for thrombosis in systemic lupus erythematosus: results from a large, multi- ethnic cohort. Ann Rheum Dis 2009, 68, 238-241.

30. Jung H., Bobba R., Su J., Shariati-Sarabi Z., Gladman D.D., Urowitz M., et al.: The protective effect of antimalarial drugs on thrombovascular events in systemic lupus erythematosus. Arthritis Rheum 2010, 62, 863-868.

31. Gómez-Guzmán M., Jiménez R., Romero M., Sánchez M., Zarzuelo M.J., Gómez-Morales M., et al.: Chronic hydroxychloroquine improves endothelial dysfunction and protects kidney in a mouse model of systemic lupus erythematosus. Hypertension $2014,64,330-337$

32. Liu D., Li X., Zhang Y., Sum-Wing Kwong J., Li L., Zhang Y., et al.: Chloroquine and hydroxychloroquine are associated with reduced cardiovascular risk: a systematic review and meta-analysis. Drug Des Devel Ther 2018, 12, $1685-1695$.

33. Gupta A., Shields K.J., Manzi S., Wasko M.C., Sharma T.S.: Association of hydroxychloroquine use with reduced risk of incident atrial fibrillation in lupus. Arthritis Care Res 2021, 73, 828-832.

34. Barnard R.A., Wittenburg L.A., Amaravadi R.K., Gustafson D.L., Thorburn A., Thamm D.H.: Phase I clinical trial and pharmacodynamic evaluation of combination hydroxychloroquine and doxorubicin treatment in pet dogs treated for spontaneously occurring lymphoma. Autophagy 2014, 10, 1415-1425.

35. Rosenfeld M.R., Ye X., Supko J.G., Desideri S., Grossman S.A., Brem S., et al.: A phase I/II trial of hydroxychloroquine in conjunction with radiation therapy and concurrent and adjuvant temozolomide in patients with newly diagnosed glioblastoma multiforme. Autophagy 2014, 10, 1359-1368.

36. Lyu X., Zeng L., Zhang H., Ke Y., Liu X., Zhao N., et al.: Hydroxychloroquine suppresses lung tumorigenesis via inducing FoxO3a nuclear translocation through STAT3 inactivation. Life Sci 2020, 246, 117366.

37. Ruiz-Irastorza G., Ugarte A., Egurbide M.V., Garmendia M., Pijoan J.I., Martinez-Berriotxoa A., et al.: Antimalarials may influence the risk of malignancy in systemic lupus erythematosus. Ann Rheum Dis 2007, 66, 815-817.

38. Fanouriakis A., Kostopoulou M., Alunno A., Aringer M., Bajema I., Boletis J.N., et al.: 2019 update of the EULAR recommendations for the management of systemic lupus erythematosus. Ann Rheum Dis 2019, 78, 736-745.

39. Andreoli L., Bertsias G.K., Agmon-Levin N., Brown S., Cervera R., Costedoat-Chalumeau N., et al.: EULAR recommendations for women's health and the management of family planning, assisted reproduction, pregnancy and menopause in patients with systemic lupus erythematosus and/or antiphospholipid syndrome. Ann Rheum Dis 2017, 76, 476-485.

40. Cartella S., Cavazzana I., Ceribelli A., Inverardi F., Tincani A., Franceschini F.: Evaluation of mortality, disease activity, treatment, clinical and immunological features of adult and late onset systemic lupus erythematosus. Autoimmunity 2013, 46, 363-368.

41. Jorge A., McCormick N., Lu N., Zheng Y., Esdaile J., De Vera M., et al.: Hydroxychloroquine and mortality among patients with systemic lupus erythematosus in the general population. Arthritis Care Res (Hoboken) 2020, 14;10.1002/acr.24255. doi: 10.1002/ acr.24255.

42. Mena-Vázquez N., Fernández-Nebro A., Pego-Reigosa J.M., Galindo M., Melissa-Anzola A., Uriarte-Isacelay E., et al.: Hydroxychloroquine is associated with a lower risk of polyautoimmunity: data from the RELESSER Registry. Rheumatology 2020, 59, 2043-2051. 
43. Kuhn A., Bonsmann G., Anders H.J., Herzer P., Tenbrock K., Schneider M.: The diagnosis and treatment of systemic lupus erythematosus. Dtsch Arztebl Int 2015, 112, 423-432.

44. Levy R.A., Vilela V.S., Cataldo M.J., Ramos R.C., Duarte J.L., Tura B.R., et al.: Hydroxychloroquine (HCQ) in lupus pregnancy: double-blind and placebo-controlled study. Lupus 2001, 10, 401-404.

45. Izmirly P.M., Costedoat-Chalumeau N., Pisoni C.N., Khamashta M.A., Kim M.Y., Saxena A., et al.: Maternal use of hydroxychloroquine is associated with a reduced risk of recurrent anti-SSA/Ro-antibody-associated cardiac manifestations of neonatal lupus. Circulation 2012, 126, 76-82.

46. Kuhn A., Aberer E., Bata-Csörgó Z., Caproni M., Dreher A., Frances C., et al.: S2k guideline for treatment of cutaneous lupus erythematosus - guided by the European Dermatology Forum (EDF) in cooperation with the European Academy of Dermatology and Venereology (EADV). J Eur Acad Dermatol Venereol 2017, 31, 389-404.

47. Woźniacka A., Sysa-Jędrzejowska A., Reich A., Szepietowski J., Błaszczyk M., Lis-Święty A., et al.: Cutaneous lupus erythematosus. Diagnostic and therapeutic recommendations of the Polish Dermatological Society. Dermatol Rev 2018, 105, $244-263$.

48. Smolen J.S., Landewé R.B.M., Bijlsma J.W.J., Burmester G.R., Dougados M., Kerschbaumer A., et al.: EULAR recommendations for the management of rheumatoid arthritis with synthetic and biological disease-modifying antirheumatic drugs: 2019 update. Ann Rheum Dis 2020, 79, 685-699.

49. Tektonidou M.G., Andreoli L., Limper M., Amoura Z., Cervera R., Costedoat-Chalumeau N., et al.: EULAR recommendations for the management of antiphospholipid syndrome in adults. Ann Rheum Dis 2019, 78, 1296-1304.

50. Ramos-Casals M., Brito-Zerón P., Bombardieri S., Bootsma H., De Vita S., Dörner T., et al.: EULAR recommendations for the management of Sjögren's syndrome with topical and systemic therapies. Ann Rheum Dis 2020, 79, 3-18.

51. Waldman R., DeWane M.E., Lu J.: Dermatomyositis: diagnosis and treatment. J Am Acad Dermatol 2020, 82, $283-296$.

52. Pepmueller P.H.: Undifferentiated connective tissue disease, mixed connective tissue disease, and overlap syndromes in rheumatology. Mo Med 2016, 113, 136-140.

53. Chaigne B., Scirè C.A., Talarico R., Alexander T., Amoura Z., Avcin T., et al.: Mixed connective tissue disease: state of the art on clinical practice guidelines. RMD Open 2019, 4, e000783.

54. Alves M.R., Isenberg D.A.: “Mixed connective tissue disease”: a condition in search of an identity. Clin Exp Med 2020, 20, 159166.

55. James J.A., Kim-Howard X.R., Bruner B.F., Jonsson M.K., McClain M.T., Arbuckle M.R., et al.: Hydroxychloroquine sulfate treatment is associated with later onset of systemic lupus erythematosus. Lupus 2007, 16, 401-409.

56. Olsen N.J., James J.A., Arriens C., Ishimori M.L., Wallace D.J., Kamen D.L., et al.: Study of anti-malarials in incomplete lupus erythematosus (SMILE): study protocol for a randomized controlled trial. Trials 2018, 19, 694.

57. Yang S., Ni R., Lu Y., Wang S., Xie F., Zhang C., et al.: A three-arm, multicenter, open-label randomized controlled trial of hydroxychloroquine and low-dose prednisone to treat recurrent pregnancy loss in women with undifferentiated connective tissue diseases: protocol for the Immunosuppressant regimens for Living FEtuses (ILIFE) trial. Trials 2020, $21,771$.

58. Grewal S.K., Rubin C., Rosenbach M.: Antimalarial therapy for granuloma annulare: results of a retrospective analysis. J Am Acad Dermatol 2017, 76, 765-767.

59. El Jammal T., Jamilloux Y., Gerfaud-Valentin M., Valeyre D., Sève P.: Refractory sarcoidosis: a review. Ther Clin Risk Manag 2020, 16, 323-345.

60. Imadojemu S., Rosenbach M.: Advances in inflammatory granulomatous skin diseases. Dermatol Clin 2019, 37, 49-64.

61. Arora S., Malik A., Patil C., Balki A.: Annular elastolytic giant cell granuloma: a report of 10 cases. Indian Dermatol Online J 2015, 6 (Suppl 1), S17-S20.

62. Kavala M., Sudogan S., Zindanci I., Kocaturk E., Can B., Turkoglu Z., et al.: Significant improvement in ulcerative necrobiosis lipoidica with hydroxychloroquine. Int J Dermatol 2010, 49, 467-469.

63. van der Waal R.I., Schulten E.A., van der Meij E.H., van de Scheur M.R., Starink T.M., van der Waal I.: Cheilitis granulomatosa: overview of 13 patients with long-term follow-up: results of management. Int J Dermatol 2002, 41, $225-229$.

64. Singal A.K.: Porphyria cutanea tarda: recent update. Mol Genet Metab 2019, 128, 271-281.

65. Caresse Gamret A., Sumanth Potluri V., Krishnamurthy K., Fertig R.M.: Frontal fibrosing alopecia: efficacy of treatment modalities. Int J Womens Health 2019, 11, 273-285.

66. Husein-ElAhmed H., Gieler U., Steinhoff M.: Lichen planus: a comprehensive evidence-based analysis of medical treatment. J Eur Acad Dermatol Venereol 2019, 33, 1847-1862.

67. Pareek A., Khopkar U., Sacchidanand S., Chandurkar N., Naik G.S.: Comparative study of efficacy and safety of hydroxychloroquine and chloroquine in polymorphic light eruption: a randomized, double-blind, multicentric study. Indian J Dermatol Venereol Leprol 2008, 74, 18-22.

68. Lembo S., Raimondo A.: Polymorphic light eruption: what's new in pathogenesis and management. Front Med $2018,5,252$.

69. Kumar A.B., Blixt E.K., Drage L.A., El-Azhary R.A., Wetter D.A.: Treatment of morphea with hydroxychloroquine: a retrospective review of 84 patients at Mayo Clinic, 1996-2013. J Am Acad Dermatol 2019, 80, 1658-1663.

70. Vestergaard C., Toubi E., Maurer M., Triggiani M., Ballmer-Weber B., Marsland A., et al.: Treatment of chronic spontaneous urticaria with an inadequate response to H1-antihistamines: an expert opinion. Eur J Dermatol 2017, 27, 10-19.

71. Melles R.B., Marmor M.F.: The risk of toxic retinopathy in patients on long-term hydroxychloroquine therapy. JAMA Ophthalmol 2014, 132, 1453-1460.

72. Koppikar S., Gottheil S., Farrer C., Gakhal N.: Improving hydroxychloroquine dosing and toxicity screening at a tertiary care ambulatory center: a quality improvement initiative. J Rheumatol 2021, 48, 138-144.

73. Vázquez-Otero I., Medina-Cintrón N., Arroyo-Ávila M., González-Sepúlveda L., Vilá L.M.: Clinical impact of hydroxychloroquine dose adjustment according to the American Academy of Ophthalmology guidelines in systemic lupus erythematosus. Lupus Sci Med 2020, 7, e000395.

74. Garg S., Unnithan R., Hansen K.E., Costedoat-Chalumeau N., Bartels C.M.: The clinical significance of monitoring hydroxychloroquine levels in patients with systemic lupus erythematosus: a systematic review and meta-analysis. Arthritis Care Res (Hoboken) 2021, 73, 707-716. 
75. Costedoat-Chalumeau N., Galicier L., Aumaître O., Francès C., Le Guern V., Lioté F., et al.: Hydroxychloroquine in systemic lupus erythematosus: results of a French multicentre controlled trial (PLUS Study). Ann Rheum Dis 2013, 72, 1786-1792.

76. Frances C., Cosnes A., Duhaut P., Zahr N., Soutou B., Ingen-Housz-Oro S., et al.: Low blood concentration of hydroxychloroquine in patients with refractory cutaneous lupus erythematosus: a French multicenter prospective study. Arch Dermatol 2012, $148,479-484$.

77. Kwatra S.G.: Toll-like receptor-9 signaling and decreased efficacy of antimalarial drugs in smokers with cutaneous lupus erythematosus. J Am Acad Dermatol 2015, 73, e79.

78. Kuhn A., Sigges J., Biazar C., Ruland V., Patsinakidis N., Landmann A., et al.: Influence of smoking on disease severity and antimalarial therapy in cutaneous lupus erythematosus: analysis of 1002 patients from the EUSCLE database. Br J Dermatol 2014, $171,571-579$

79. Sharma A.N., Mesinkovska N.A., Paravar T.: Characterizing the adverse dermatologic effects of hydroxychloroquine: a systematic review. J Am Acad Dermatol 2020, 83, 563-578.

80. Jallouli M., Frances C., Piette J.C., Huong Du L.T., Moguelet P., Factor C., et al.: Hydroxychloroquineinduced pigmentation in patients with systemic lupus erythematosus: a case-control study. JAMA Dermatol 2013, 149, 935-940.

81. Bahloul E., Jallouli M., Garbaa S., Marzouk S., Masmoudi A., Turki H., et al.: Hydroxychloroquine-induced hyperpigmentation in systemic diseases: prevalence, clinical features and risk factors: a cross-sectional study of 41 cases. Lupus 2017, $26,1304-1308$.

82. Samotij D., Szczęch J., Kushner C.J., Mowla R.M., Dańczak-Pazdrowska A., Antiga E., et al.: Prevalence of pruritus in cutaneous lupus erythematosus: brief report of a multicenter, multinational cross-sectional study. Biomed Res Int 2018, 25, 3491798.

83. Coleman I., Ruiz G., Brahmbhatt S., Ackerman L.: Acute generalized exanthematous pustulosis and Stevens-Johnson syndrome overlap due to hydroxychloroquine: a case report. J Med Case Rep 2020, 14, 210.

84. Rowane M., Schend J., Patel J., Hostoffer Jr. R.: Rapid desensitization of hydroxychloroquine. Ann Allergy Asthma Immunol 2020, 124, 97-99.

85. Herman S.M., Shin M.H., Holbrook A., Rosenthal D.: The role of antimalarials in the exacerbation of psoriasis: a systematic review. Am J Clin Dermatol 2006, 7, 249-257.

86. Marmor M.F., Kellner U., Lai T.Y., Melles R.B., Mieler W.F.: Recommendations on screening for chloroquine and hydroxychloroquine retinopathy (2016 Revision). Ophthalmology 2016, 123, 1386-1394.

87. Yusuf I.H., Foot B., Galloway J., Ardern-Jones M.R., Watson S.L., Yelf C., et al.: The Royal College of Ophthalmologists recommendations on screening for hydroxychloroquine and chloroquine users in the United Kingdom: executive summary. Eye 2018, 32, 1168-1173.

88. Raizman M.B., Hamrah P., Holland E.J., Kim T., Mah F.S., Rapuano C.J., et al.: Drug-induced corneal epithelial changes. Survay Ophtalmol 2017, 62, 286-301

89. Tselios K., Gladman D.D., Su J., Urowitz M.B.: Antimalarials as a risk factor for elevated muscle enzymes in systemic lupus erythematosus. Lupus 2016, 25, 532-535.

90. Tselios K., Deeb M., Gladman D.D., Harvey P., Urowitz M.B.: Antimalarial-induced cardiomyopathy: a systematic review of the literature. Lupus 2018, 27, 591-599.

91. Mohammad S., Clowse M., Eudy A., Criscione-Schreiber L.G.: Examination of hydroxychloroquine use and hemolytic anemia in G6PDH-deficient patients. Arthritis Care Res 2018, 70, 481-485.

92. Salman Mardones P., Quevedo Langenegger I., Arias Thormann M., Stehr Gesche C., Bancalari Selman A.: Hypoglycemia due to hydroxychloroquine, an uncommon association but to keep in mind, case report and review of literature. J Diabetes Metab Disord Control 2020, 7, 6-7.

93. Polanski J.F., Tanaka E.A., Barros H., Chuchene A.G., Miguel P.T.G., Skare T.L.: Chloroquine, hydroxychloroquine and hearing loss: a study in systemic lupus erythematosus patients. Laryngoscope 2021, 131, E957-E960.

Received: 26.03 .2021

Accepted: 17.05 .2021

Otrzymano: $26.03 .2021 \mathrm{r}$.

Zaakceptowano: $17.05 .2021 \mathrm{r}$.

How to cite this article:

Dańczak-Pazdrowska A., Polańska A.: The place of hydroxychloroquine in modern dermatology. Dermatol Rev/Przegl Dermatol 2021, 108, 178-190. DOI: https://doi.org/10.5114/dr.2021.108614. 